\title{
INVESTIGATION OF THE EFFECT OF BORON NITRIDE AND COLEMANITE ON THE PROPERTIES OF POLYVINYL CHLORIDE
}

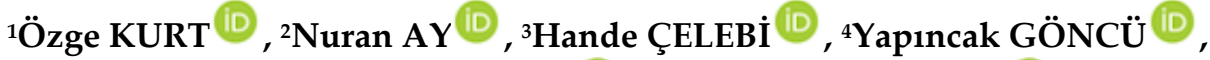 \\ ${ }^{5}$ Mustafa Erdem ÜREYEN (D), ${ }^{6}$ Meltem GÜNAY TEK ${ }^{(D)}$ \\ 1,3 Eskisehir Technical University, Department of Chemical Engineering, Eskisehir, TURKEY \\ ${ }^{2}$ Eskisehir Technical University, Department of Materials Science and Engineering, Eskisehir, TURKEY \\ ${ }^{4}$ Eskisehir Osmangazi University, Department of Biomedical Engineering, Eskisehir, TURKEY \\ ${ }^{5}$ Eskisehir Technical University, Textile and Fashion Design Department, Eskisehir, TURKEY \\ ${ }^{6}$ Nursan Cable Hardware Industry and Trade Co., RED Engineer, Kutahya, TURKEY \\ ${ }^{1}$ ozgekurt@eskisehir.edu.tr, ${ }^{2}$ nay@eskisehir.edu.tr, ${ }^{3}$ handed@eskisehir.edu.tr, \\ ${ }^{4}$ yapincak.goncu@ogu.edu.tr, ${ }^{5}$ meureyen@eskisehir.edu.tr, ${ }^{6}$ mgunay@nursankd.com
}

(Geliş/Received: 16.08.2021; Kabul/Accepted in Revised Form: 28.12.2021)

\begin{abstract}
Polyvinyl chloride (PVC) is used as an insulator in cable production. In order to enhance its thermal stability and flame retardant properties various chemicals have been added to PVC. In this study, hexagonal boron nitride $(\mathrm{BN})$ and colemanite $(\mathrm{C})$ at different concentrations were added to PVC to prepare composites by melt compounding method. The effect of formulation on the properties of PVC composites were observed. The thermal stability of PVC composites was determined by using a PVC Thermomat device. LOI (Limiting Oxygen Index) tests were performed to examine combustion characteristics. The mechanical properties of the composites were conducted by tensile tests. BN and C had a positive effect on the thermal stability of PVC. PVC remained stable for 3.74 hours at $210^{\circ} \mathrm{C}$. Addition of $\mathrm{BN}$ and C $(1$ wt.\% of the amount stabilizer) increased stability time to 4.16 hours, and 5.50 hours, respectively. The composite in which BN and $\mathrm{C}$ were used together remained stable for 5.74 hours. LOI value of $\mathrm{BN}$ and $\mathrm{C}$ added composite did not change noticeably, compared to neat PVC. The mechanical properties of composites remained within acceptable limits for being used in cable production. In brief, addition of BN or C to PVC is an effective technique to produce cables with improved properties for various applications.
\end{abstract}

Keywords: PVC, Boron nitride, Colemanite, Polymer composite, Thermal stability, LOI, Tensile properties

\section{Polivinil Klorürün Özelliklerine Bor Nitrür ve Kolemanit Etkisinin İncelenmesi}

ÖZ: Polivinil klorür (PVC), kablo üretiminde yalıtkan olarak kullanılır. Isıl kararlılık ve alev geciktirici özelliğinin geliştirilmesi için çeşitli kimyasallar ilave edilir. Bu çalışmada, PVC'ye farklı derişimlerde hekzagonal bor nitrür $(\mathrm{BN})$ ve kolemanit $(\mathrm{C})$ eriyik karıştırma yöntemiyle eklenmiştir. Formülasyonun PVC kompozitleri üzerine etkisi incelenmiştir. PVC kompozitlerinin 1sıl kararlılıkları PVC Thermomat cihazı ile ölçülmüştür. Yanma özelliklerini incelemek için LOI (Limit Oksijen Indeksi) testleri yapılmıştır. Kompozitlerin mekanik özellikleri ise çekme testi ile belirlenmiştir. BN ve C'nin PVC'nin $1 s ı l$ kararlılığına olumlu etkisi olmuştur. Saf PVC $210^{\circ} \mathrm{C}^{\prime}$ de 3,74 saat kararlı kalmıştır. BN ve C (stabilizan miktarının \%1'i kadar) eklenmesi ile 1 sıl kararlılıkları sırasıyla 4,16 saat ve 5,50 saate çıkmıştır. BN ve C'nin birlikte kullanıldığı kompozit ise 5,74 saat kararlı kalmıştır. BN ve C ilave edilmiş kompozitin LOI değeri, saf PVC'ye kıyasla belirgin bir değişim göstermemiştir. Kompozitlerin mekanik değerleri kablo üretiminde kullanılabilir limitler içerisindedir. Özetle, PVC'ye BN veya C ilavesinin çeşitli uygulamalarda 
kullanılmak üzere gelişmiş özelliklere sahip kablolar üretmek için etkili bir teknik olduğu sonucuna varılmıştır.

Anahtar Kelimeler: PVC, Bor nitrür, Kolemanit, Polimer kompozit, Termal kararlilık, LOI, Çekme özellikleri

\section{INTRODUCTION}

Composite can be defined as a polyphase material consisting of two or more components with different properties and shapes. Composite materials show unique properties as well as maintaining the main features of their original components. They are preferred due to their advantages such as low weight, high fatigue strength, high specific strength, corrosion resistance, and fast assembly. Composite materials are used in aerospace industry, transportation and construction industry, chemical corrosion equipment, and electrical or electronic devices (Wang, Zheng et al., 2011).

PVC is a polymer in the form of a white powder and colorless granules obtained by polymerization from vinyl chloride monomer with the help of various additives. Moreover, PVC is an insulator, and it is resistant to acids, oils, and hydrocarbons. It can be elastic or rigid depending on its formulation (plasticizers, stabilizers, fillers such as calcite, and some other additives) (Baydar, 2016, Haruna, Pekdemir et al., 2020). In recent years, studies have been focused on modifying PVC with inorganic fillers (Pekdemir, 2020). The most common methods used for processing PVC are extrusion, injection molding, vacuum forming, and rotational molding (Baydar, 2016).

BN is a heat-resistant material and due to its interesting physical and chemical properties, it has been used in many applications. The distinctive combination of thermal, mechanical, and electrical properties found in hexagonal boron nitride has attracted attention in the material design of various industrial applications. The application of $\mathrm{BN}$ has gained tremendous importance both as a refractory and a lubricant. In addition, $\mathrm{BN}$ has unique properties such as high thermal conductivity, low thermal expansion, good thermal shock resistance, high electrical resistance, low dielectric constant. BN is nontoxic, comfortably processed, non-corrosive, lubricating, chemically inert, and is non-wetting by most molten metals (Joni, Balgis et al., 2011, Ay, Ay et al., 2016).

The unique structure and bonding properties of borate have played a significant role in modern industrial applications. They are widely used in high-tech ceramics, cleaning-bleaching, metallurgy, energy, agriculture and plumbing industries, and other engineering materials containing mainly boron or its compounds. Calcium borate (Colemanite, $2 \mathrm{CaO}_{3} 3 \mathrm{~B}_{2} \mathrm{O}_{3} .5 \mathrm{H}_{2} \mathrm{O}$ ) is a natural mineral. It is the most common of the boron compounds and exists as large, shiny, transparent crystals in the cavities within the clays. Dissolution of pure colemanite is slow in water and very rapid in $\mathrm{HCl}$ (Sahin, 2011). Due to this feature, it is used as a flame retardant additive in phosphorus and halogen containing materials. It reacts with $\mathrm{HCl}$ during combustion, which prevents toxic gas emission (Kaymakçı O., 2017). The world's largest colemanite deposits are in Turkey (Helvac1, 2017).

Jan et al., produced PVC polymer composites by adding hexagonal boron nitride at three different sizes. The favorable alignment and homogenous distribution of BN in PVC resulted in improved mechanical properties (Jan, Sadiq et al., 2017). Madakbaş et al., added BN to improve the flame retardant and thermal stability properties of the polyacrylonitrile (PAN) polymer. PAN fibers are commonly known as "acrylic fibers" and these materials are highly flammable. BN was used as a flame retardant to eliminate this feature. PAN/BN composites were prepared by using solution casting technique. PAN/BN composites had high thermal stability and increased flame retardancy properties (Madakbaş, Çakmakçı et al., 2013). Kaymakçı et al., added 17-25\% colemanite to PVC for enhancing thermal and flame resistance of PVCbased refrigerator door seals. They reported that colemanite delayed the break-out and spread of a fire by providing endothermic water diffusion during the fire. Furthermore, the cracked colemanite formed an oxidative protective layer (Kaymakçı O., 2017).

In this study, $\mathrm{BN}$ and $\mathrm{C}$ were used as additives to increase thermal stability and flame retardant properties of PVC used in cable production for automotive industry. The additives in different proportions were added to PVC by melt compounding method. In addition, the effect of BN silanization 
on the properties of composites was investigated. The composites were characterized in terms of thermal stability, combustion, morphology and tensile properties.

\section{MATERIAL AND METHOD}

\subsection{Materials}

PVC and additives (plasticizer, stabilizer, calcite, fillers) (Nursan Cable Inc. Co.), BN (BORTEK Boron Technologies and Mechatronics Inc. Co.), C (ETI MADEN) were used to prepare composites. Surface of BN was modified with two different types of silane; vinyltrimethoxysilane and 3Aminopropyltriethoxysilane and BN particles were denoted as VTSBN and AMINOBN, respectively. The silanization procedure was described by the author's previous work (Seyhan, Göncü et al., 2017).

\subsubsection{Preparation of PVC composites}

Firstly, PVC, plasticizer, stabilizer, calcite, and other fillers were mixed in a mechanical stirrer. The homogeneously prepared mixtures were fed in a co-rotating, twin-screw compounder (DSM Xplore 15 $\mathrm{mL}$ Micro Compounder). The temperature profile of compounder having three heating zones was $170^{\circ} \mathrm{C}$ $-170^{\circ} \mathrm{C}-185^{\circ} \mathrm{C}$. The mixture was compounded at $100 \mathrm{rpm}$ for 3 minutes. The melt was taken via transfer cylinder into $12 \mathrm{ml}$ DSM Xplore Micro Injection Molding Machine for preparing standard test samples. Cylinder temperature, mold temperature, and injection pressure were $185^{\circ} \mathrm{C}, 30^{\circ} \mathrm{C}$, and 8 bar, respectively.

The standard recipe containing stabilizer and calcite in its formulation used by Nursan company was denoted as PVC-100S, and used as reference sample. The resulting composites were designated according to the amount of stabilizer and filler (Table 1). For example, in PVC-100S-1BN sample, BN was added to the mixture $1 \% \mathrm{wt}$. of the stabilizer. In PVC-100S-50C sample, C was added $50 \%$ of the stabilizer. In the PVC-X-100S-50C sample, the expression "- $X$ " indicates that as much calcite was removed as C added.

Table 1. Composition of PVC and PVC composites

\begin{tabular}{|l|l|l|l|l|l|l|}
\hline & Sample & $\begin{array}{l}\text { PVC } \\
\text { (phr) }\end{array}$ & $\begin{array}{l}\text { Stabilizer } \\
\text { (phr) }\end{array}$ & $\begin{array}{l}\text { BN } \\
\text { (phr) }\end{array}$ & $\begin{array}{l}\mathbf{C} \\
\text { (phr) }\end{array}$ & $\begin{array}{l}\text { Calcite } \\
\text { (phr) }\end{array}$ \\
\hline $\mathbf{1}$ & PVC-100S & 100 & 14 & 0 & 0 & 16 \\
\hline $\mathbf{2}$ & PVC-100S-0.5BN & 100 & 14 & 0.07 & 0 & 16 \\
\hline $\mathbf{3}$ & PVC-100S-1BN & 100 & 14 & 0.14 & 0 & 16 \\
\hline $\mathbf{4}$ & PVC-100S-1VTSBN & 100 & 14 & 0.14 & 0 & 16 \\
\hline $\mathbf{5}$ & PVC-100S-1AMINOBN & 100 & 14 & 0.14 & 0 & 16 \\
\hline $\mathbf{6}$ & PVC-100S-50BN & 100 & 14 & 7.00 & 0 & 16 \\
\hline $\mathbf{7}$ & PVC-0S-1BN & 100 & 0 & 0.14 & 0 & 16 \\
\hline $\mathbf{8}$ & PVC-100S-1C & 100 & 14 & 0 & 0.14 & 16 \\
\hline $\mathbf{9}$ & PVC-0S-1C & 100 & 0 & 0 & 0.14 & 16 \\
\hline $\mathbf{1 0}$ & PVC-100S-50C & 100 & 14 & 0 & 7.00 & 16 \\
\hline $\mathbf{1 1}$ & PVC-X-100S-50C & 100 & 14 & 0 & 7.00 & 8 \\
\hline $\mathbf{1 2}$ & PVC-X-100S-0.5BN-50C & 100 & 14 & 0.07 & 7.00 & 8 \\
\hline
\end{tabular}

\subsubsection{Characterization}

\subsubsection{Characterization of $B N$ and $C$}

The surface morphology of BN and C was examined by using a ZEISS SUPRA VP50 Scanning Electron Microscope (SEM) at a voltage of $15-20 \mathrm{kV}$. The sample surfaces were coated with palladium for $40 \mathrm{~s}$ by AGAR sputter coater to avoid charging before the morphological analysis of composites. 
In order to evaluate the crystalline structure of $\mathrm{BN}$ and $\mathrm{C}$ they were characterized by $\mathrm{X}$-ray diffraction (XRD) using a Rikagu Miniflex 600 X-ray diffractometer with CuK $\alpha$ radiation $(\lambda=1.5418 \AA$ ). The scan speed was $2^{\circ} / \mathrm{min}$, and XRD data were collected from 10 to $60^{\circ}(2 \theta)$ and from 10 to $80^{\circ}(2 \theta)$ for $\mathrm{BN}$ and $\mathrm{C}$, respectively.

The particle size and distribution of $\mathrm{BN}$ and $\mathrm{C}$ were determined by laser diffraction method using a Malvern Mastersizer 2000.

\subsubsection{Characterization of composites}

The thermal stability of PVC composites was measured using a Metrohm - 895 PVC Thermomat device at $210^{\circ} \mathrm{C}$ according to ISO $182-3$ standard. The evolved $\mathrm{HCl}$ gas during decomposition was released into nitrogen gas environment and then passed through a vessel where it was absorbed in pure water. The change in conductivity of water was measured. Stability time was defined as the point at which $50 \mu \mathrm{S} / \mathrm{cm}$ increase was achieved from the beginning of the experiment. The induction time was defined as the time to reach the peak point of the derivative of conductivity curve.

Combustion behavior of PVC composites was evaluated using Limit Oxygen Index (LOI) measurements by using a Dynisco Limiting Oxygen Index Analyzer instrument according to ASTM D2863-10 standards. Materials with LOI value less than $21 \%$ and greater than $21 \%$ are defined as easily combustible and self-extinguishing, respectively (John, 2018). When the LOI value exceeds $26-28 \%$, the samples are classed as flame retardant materials (Horrocks, Tune et al., 1988, Lu and Hamerton, 2002, Chen, Zheng et al., 2006).

Tensile properties of PVC composites were conducted using an Instron 5944 tensile testing machine at a crosshead speed of $50 \mathrm{~mm} / \mathrm{min}$ according to ISO 527-5A standards. Reproducibility of tensile tests was determined for PVC-100S-1BN composite. Three batches were prepared at 3 different times and tensile test results were evaluated.

The surface morphologies of the fractured specimens resulting from tensile tests were analyzed by SEM (ZEISS SUPRA VP50). Before the analysis, each sample was coated with palladium-gold by AGAR sputter-coating instrument for 40 seconds.

\section{RESULTS AND DISCUSSION}

\subsection{Characterization of $\mathrm{BN}$ and $\mathrm{C}$}

The hexagonal crystalline structure of BN is shown in Figure 1-a. The sample had a layered structure containing agglomerates (Rudolph 1993). Figure 1-b shows the non-porous crystal structure of C. The particle size distribution analysis revealed that the average sizes of $B N$ and $C$ were $0.121 \mu \mathrm{m}$ and 28.135 $\mu \mathrm{m}$, respectively. Colemanite particle size was reduced to $6.177 \mu \mathrm{m}$ by grinding in order to obtain a homogeneous PVC composition. 

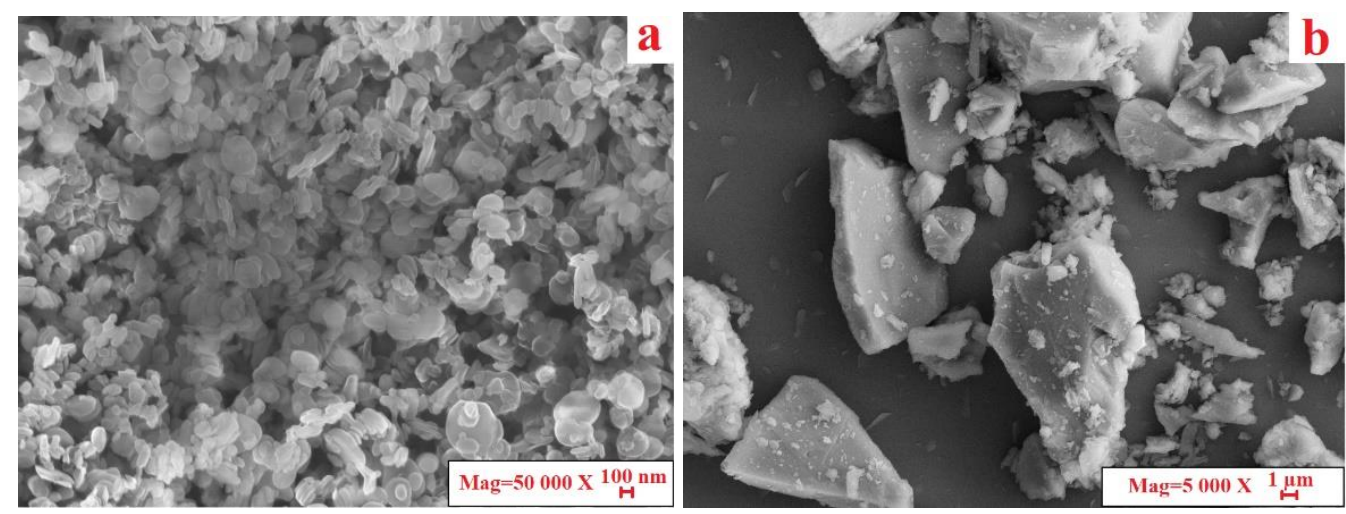

Figure 1. SEM images of a) BN (50 $000 \mathrm{X})$ and b) C (5000 X)

The XRD patterns of BN and C are shown in Figure 2. The sharp and well-defined characteristic peak of $B N$ was observed at $2 \theta=26.8^{\circ}$. In the XRD pattern of $C$ it was clearly noticed that the sample contains materials such as quartz and calcite as well as C.
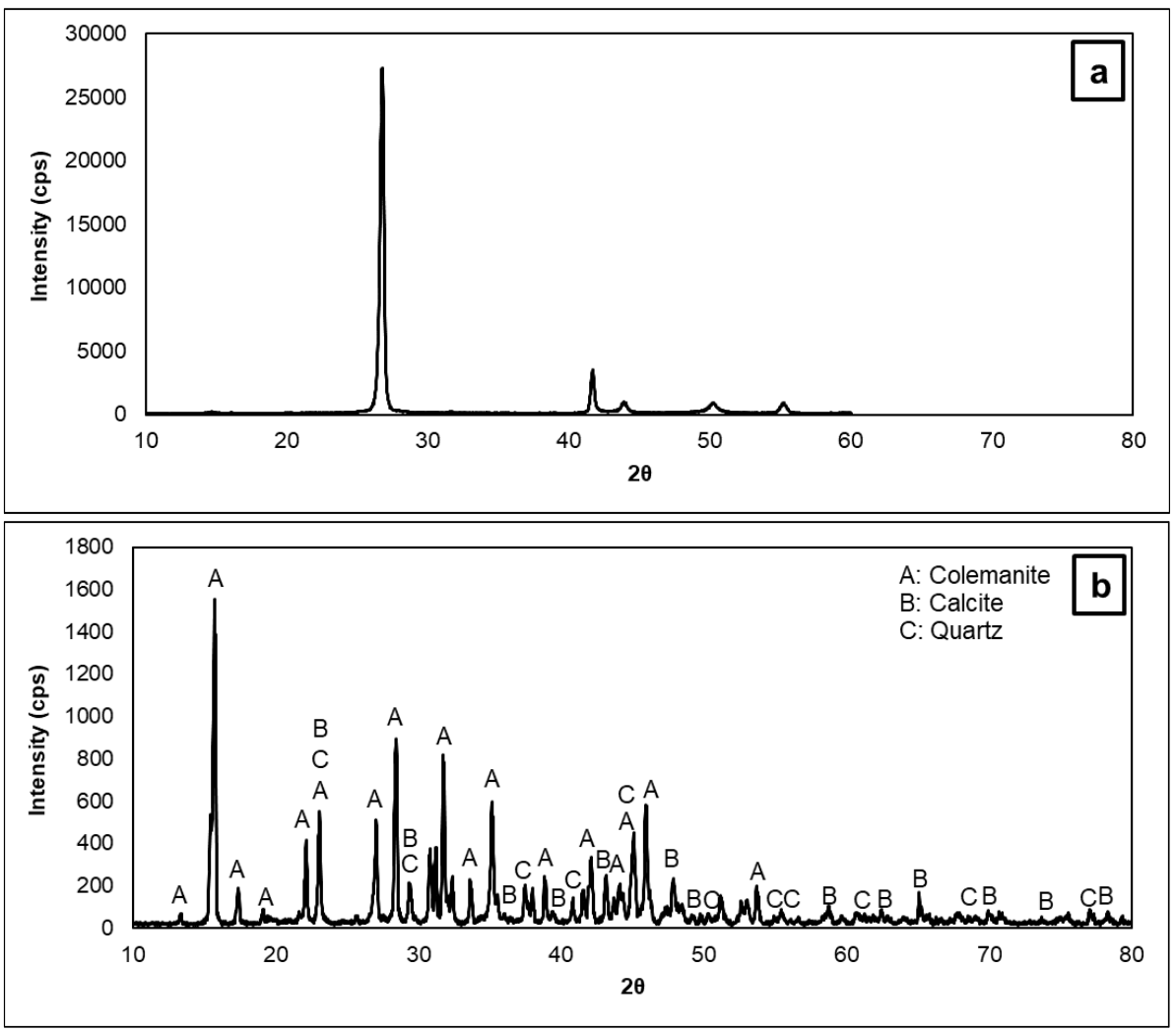

Figure 2. $X R D$ pattern of a) $B N$ and b) $C$

\subsection{Characterization of composites}

Thermal stability of PVC composites are represented in Table 2. The stability time and induction time of PVC-100S were $3.74 \mathrm{~h}$ and $3.62 \mathrm{~h}$, respectively. The complete removal of the stabilizer and adding BN (PVC-0S-1BN) or C (PVC-0S-1C) instead, affected the thermal stability negatively. It is proposed that stabilizer cannot be replaced by $\mathrm{BN}$ or $\mathrm{C}$. However, using stabilizer- $\mathrm{BN}$ or stabilizer- $\mathrm{C}$ together increased stability time and induction time considerably compared to reference sample. Increasing amount of $\mathrm{C}$, which is more cost-effective than $\mathrm{BN}$, improved thermal stability of composites. The composites with reduced calcite content as much as the amount of C designated by -X (PVC-X-100S-50C) had higher 
thermal stability than PVC-100S-50C composite. The calcite amount was also reduced in composite (PVC$\mathrm{X}-100 \mathrm{~S}-0.5 \mathrm{BN}-50 \mathrm{C}$ ) containing both $\mathrm{BN}$ and $\mathrm{C}$ to prevent the decrease in thermal stability. Its stability was higher than the reference sample but lower than the composite using only C (PVC-X-100S-50C). Baydar reported that thermal stability of PVC sample was $0.67 \mathrm{~h}$ at $200^{\circ} \mathrm{C}$ (Baydar, 2016). Atakul measured induction time of PVC as $2.3 \mathrm{~h}$ at $160^{\circ} \mathrm{C}$ (Atakul, 2004). The difference in thermal stability values was probably due to variety of PVC composition.

LOI values of the composites are represented in Table 2. LOI of PVC-100S composite was $25 \%$. Sang et al. reported that LOI value of neat PVC was 25.8, corresponding to its inherent flammability (Sang et al., 2017). LOI values of PVC-100S-1BN, PVC-100S-1VTSBN, and PVC-X-100S-0.5BN-50C composites were $25.5 \%, 25.7 \%$, and $25.3 \%$, respectively. It is remarkable that LOI values of composites are close to each other. Low concentration of $\mathrm{BN}$ in composites might be the reason why the combustion properties did not change (Dogan, Dogan et al., 2021).

Table 2. Thermal stability and LOI results of composites

\begin{tabular}{|l|l|l|l|l|}
\hline & Sample & $\begin{array}{l}\text { Stability } \\
\text { time (h) }\end{array}$ & $\begin{array}{l}\text { Induction } \\
\text { time (h) }\end{array}$ & LOI (\%) \\
\hline $\mathbf{1}$ & PVC-100S & $3.74 \pm 0.04$ & $3.62 \pm 0.44$ & 25.0 \\
\hline $\mathbf{2}$ & PVC-100S-0.5BN & $5.62 \pm 0.10$ & $5.38 \pm 0.10$ & 24.2 \\
\hline $\mathbf{3}$ & PVC-100S-1BN & $4.16 \pm 0.11$ & $4.01 \pm 0.19$ & 25.5 \\
\hline $\mathbf{4}$ & PVC-100S-1VTSBN & $2.35 \pm 0.10$ & $2.25 \pm 0.10$ & 25.7 \\
\hline $\mathbf{5}$ & PVC-100S-1AMINOBN & $3.10 \pm 0.04$ & $3.08 \pm 0.06$ & 24.6 \\
\hline $\mathbf{6}$ & PVC-100S-50BN & $3.57 \pm 0.11$ & $3.56 \pm 0.25$ & 25.6 \\
\hline $\mathbf{7}$ & PVC-0S-1BN & $1.78 \pm 0.01$ & $0.52 \pm 0.02$ & 24.1 \\
\hline $\mathbf{8}$ & PVC-100S-1C & $5.50 \pm 0.31$ & $5.24 \pm 0.23$ & 24.7 \\
\hline $\mathbf{9}$ & PVC-0S-1C & $1.98 \pm 0.08$ & $0.5 \pm 0.03$ & 24.3 \\
\hline $\mathbf{1 0}$ & PVC-100S-50C & $5.68 \pm 0.54$ & $5.47 \pm 0.36$ & 24.9 \\
\hline $\mathbf{1 1}$ & PVC-X-100S-50C & $6.08 \pm 0.11$ & $5.87 \pm 0.12$ & 24.7 \\
\hline $\mathbf{1 2}$ & PVC-X-100S-0.5BN-50C & $5.74 \pm 0.64$ & $5.33 \pm 0.84$ & 25.3 \\
\hline
\end{tabular}

The tensile properties of the PVC composites are given in Table 3. The highest tensile strength and elongation at break was seen with PVC-100S-1BN. However, modification of BN with silane groups did not have a remarkable positive effect on the tensile properties. It seems that surface modification was not enough to distribute particles homogenously in PVC. All composites complied with the production standards of Nursan company and were suitable for cable use. The beneficial impact of BN on thermal stability and mechanical properties were consistent with the studies in literature (Madakbaş, Çakmakçı et al. 2013, Jan, Sadiq et al., 2017). Reproducibility of the tensile test results of PVC-100S-1BN composite is presented in Figure 3-4. Tensile strength and elongation at break results of 3 batches were close to each other. Average of tensile strength at break values ranging from 17.9 to $19.5 \mathrm{MPa}$ (standard deviations ranging from 0.6 to 1.2), and average of elongation at break values ranging from 128.0 to $154.0 \%$ (standard deviations ranging from 4.9 to 16.7) revealed that production of composites was reproducible. 
Table 3. Tensile test results of composites

\begin{tabular}{|l|l|l|l|}
\hline & Sample & $\begin{array}{l}\text { Tensile } \\
\text { strength at } \\
\text { break (MPa) }\end{array}$ & $\begin{array}{l}\text { Elongation } \\
\text { at break (\%) }\end{array}$ \\
\hline $\mathbf{1}$ & PVC-100S & $15.7 \pm 0.5$ & $73.1 \pm 13.4$ \\
\hline $\mathbf{2}$ & PVC-100S-0.5BN & $16.8 \pm 1.9$ & $75.4 \pm 8.4$ \\
\hline $\mathbf{3}$ & PVC-100S-1BN & $18.8 \pm 1.0$ & $142.7 \pm 15.6$ \\
\hline $\mathbf{4}$ & PVC-100S-1VTSBN & $14.6 \pm 0.7$ & $63.4 \pm 1.3$ \\
\hline $\mathbf{5}$ & PVC-100S-1AMINOBN & $18.3 \pm 0.3$ & $59.8 \pm 2.1$ \\
\hline $\mathbf{6}$ & PVC-100S-50BN & $13.7 \pm 1.2$ & $64.9 \pm 1.8$ \\
\hline $\mathbf{7}$ & PVC-0S-1BN & $15.2 \pm 0.2$ & $72.1 \pm 4.1$ \\
\hline $\mathbf{8}$ & PVC-100S-1C & $13.8 \pm 0.8$ & $60.3 \pm 2.7$ \\
\hline $\mathbf{9}$ & PVC-0S-1C & $14.8 \pm 0.3$ & $80.9 \pm 8.5$ \\
\hline $\mathbf{1 0}$ & PVC-100S-50C & $13.5 \pm 1.9$ & $69.7 \pm 1.2$ \\
\hline $\mathbf{1 1}$ & PVC-X-100S-50C & $15.1 \pm 1.8$ & $70.4 \pm 0.8$ \\
\hline $\mathbf{1 2}$ & PVC-X-100S-0.5BN-50C & $17.0 \pm 2.5$ & $60.4 \pm 0.3$ \\
\hline
\end{tabular}

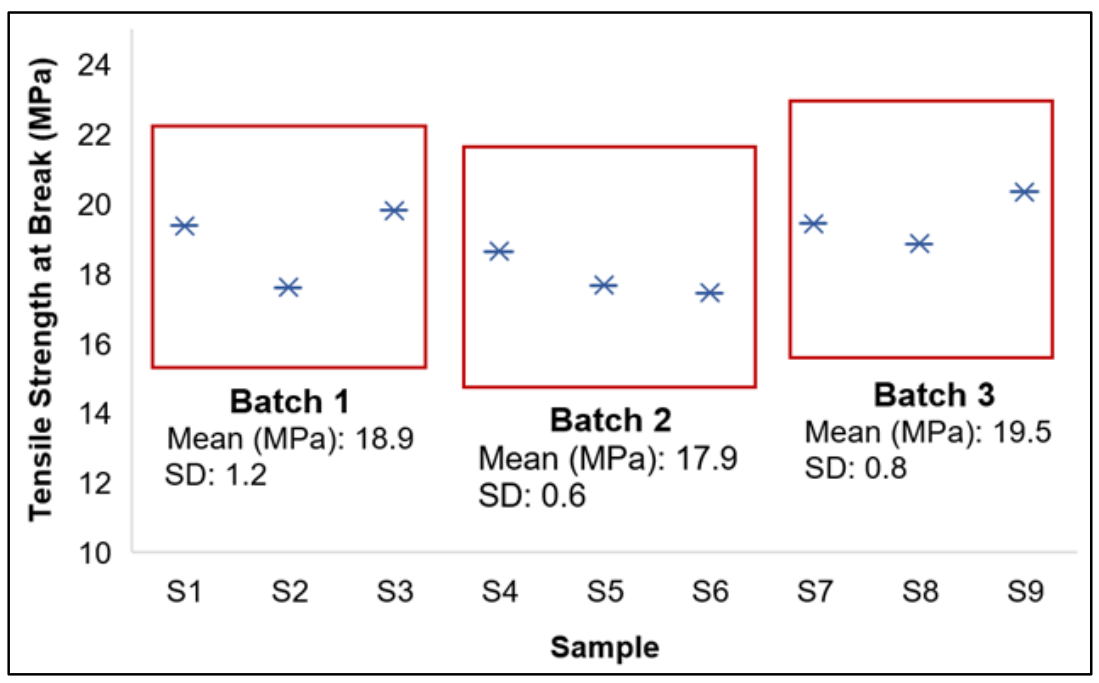

Figure 3. Reproducibility of tensile strength at break results

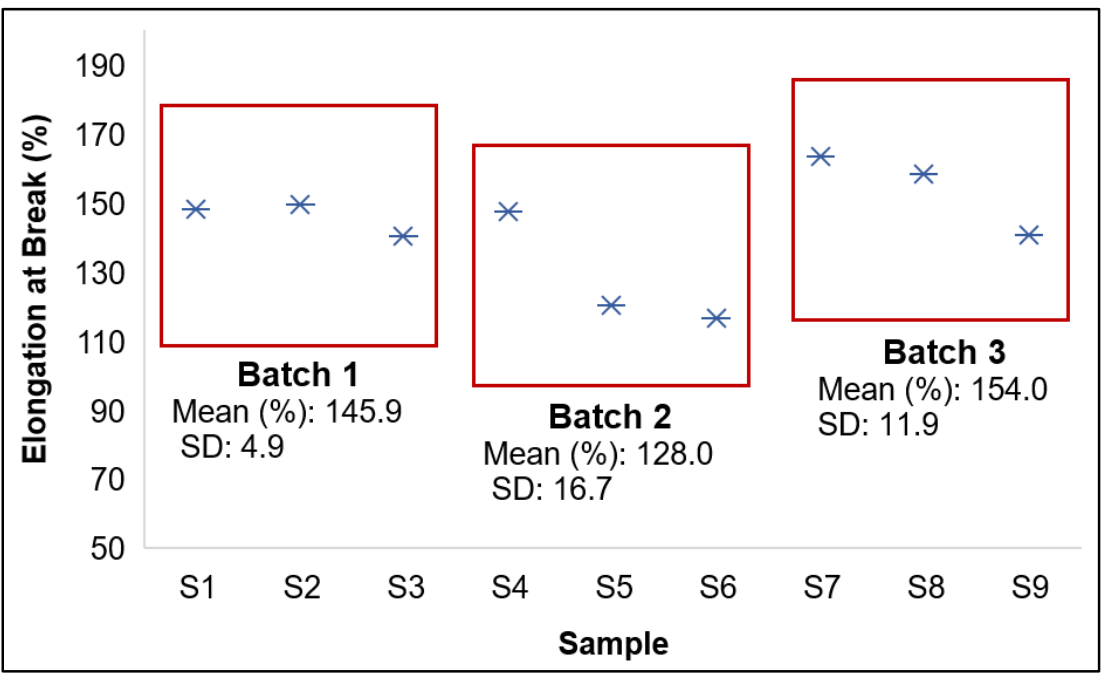

Figure 4. Reproducibility of elongation at break results 
SEM images conducted to observe the surface morphologies of the fractured specimens are given in Figure 5-a-d. It was observed that PVC-100S and PVC-100S-1BN composites exhibited rough and irregular fracture surfaces. BN was not detected throughout the PVC matrix probably due to its low concentration. On the other hand, C particles in PVC was observed in SEM images of PVC-X-100S-50C and PVC-X-100S0.5BN-50C composites. SEM images of PVC composites containing C (Figure 5c-d) show that C exhibited a good distribution throughout PVC matrix.
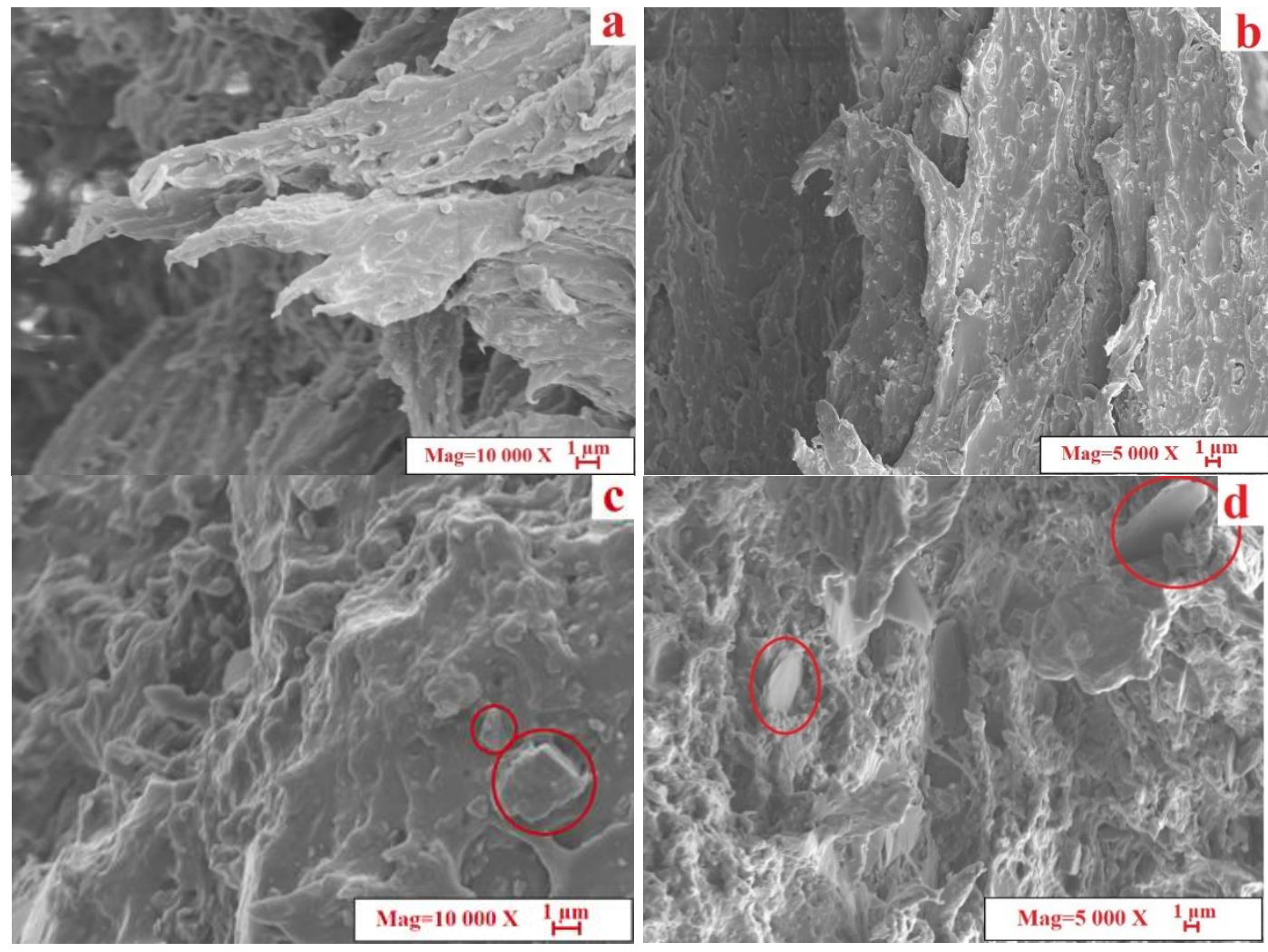

Figure 5. SEM images of composites a) PVC-100S (10 000 X), b: PVC-100S-1BN (5 $000 \mathrm{X})$, c: PVC-X-100S50C (10 000 X), d: PVC-X-100S-0.5BN-50C (5 000 X)

\section{CONCLUSION}

In this study, boron nitride and colemanite were successfully mixed with PVC by melt compounding method. The results showed that boron nitride and colemanite could not completely replace stabilizers (PVC-0S-1BN and PVC-0S-1C). Instead, they can be added in certain proportions. The use of boron nitride and/or colemanite with the stabilizer increased the thermal stability of composites. The maximum thermal stability was obtained with PVC-X-100S-50C composite. It was observed that BN silanization did not effect thermal stability of composites. Although LOI values of some PVC composites increased slightly, there was not a noticeable improvement compared to reference sample. PVC-100S-1BN had the highest tensile strength at break and elongation at break values. The results revealed that both boron nitride and colemanite additives were usable as additives into PVC. All prepared composites were suitable for cable production. The method used in this study was effective to develop composites for various engineering applications.

\section{ACKNOWLEDGEMENT}

This work was supported by the Scientific and Technological Research Council of Turkey (TUBITAK) TEYDEB 1505 University-Industry Cooperation Support Program (Project no. 5170024 and Council of 
Higher Education (YOK) Ph.D. Scholarship Program (100/2000). (Author, Özge Kurt is YOK 100/2000 scholarship student).

\section{REFERENCES}

Atakul, S., 2004, "Synergistic Effect of Zinc Stearate and Natural Zeolite on PVC Thermal Stability", Izmir Institute of Technology, Izmir.

Ay, N., Ay G. M., Göncü Y., 2016, "Environmentally friendly material: Hexagonal boron nitride." Bor Dergisi 1(2): 66-73.

Baydar, E., 2016, "Farkl dolgu maddeli PVC kompozit malzemelerinin üretimi ve özelliklerinin incelenmesi", Selçuk Üniversitesi Fen Bilimleri Enstitüsü, Konya.

Chen, S., Zheng Q. k., Ye, G. d., Zheng G. k., 2006, "Fire-retardant properties of the viscose rayon containing alkoxycyclotriphosphazene." Journal of Applied Polymer Science 102(1): 698-702.

Dogan, M., Dogan, S. D., Savas, L. A., Ozcelik, G., Tayfun, U. 2021, "Flame retardant effect of boron compounds in polymeric materials." Composites Part B: Engineering: 109088.

Haruna, H., Pekdemir, M. E., Tukur, A., Coşkun, M., 2020, "Characterization, thermal and electrical properties of aminated PVC/oxidized MWCNT composites doped with nanographite." Journal of Thermal Analysis and Calorimetry 139(6): 3887-3895.

Helvac1, C., 2017, "Borate deposits: An overview and future forecast with regard to mineral deposits." Journal of Boron 2(2): 59-70.

Horrocks, A. R., Tune M., Cegielka L., 1988, "The burning behaviour of textiles and its assessment by oxygen-index methods." Textile Progress 18(1-3): 1-186.

Jan, R., Sadiq M., Hussain A., 2017, "Boron nitride-polymer composites: Mechanical properties evaluation at various strain ratios." 2017 14th International Bhurban Conference on Applied Sciences and Technology (IBCAST), IEEE.

John, M. J., 2019, “Chapter 2 - Flammability performance of biocomposites”, Green composites for automotive applications, Koronis, G., Silva A., Woodhead Publishing, 43-28.

Joni, I. M., Balgis R., Ogi T., Iwaki T., Okuyama K., 2011, "Surface functionalization for dispersing and stabilizing hexagonal boron nitride nanoparticle by bead milling." Colloids and Surfaces A: Physicochemical and Engineering Aspects 388(1-3): 49-58.

Kaymakçı O., Y. B., 2017, "Flame-Resistant PVC Composition for Refrigerator Door Gasket." $\mathrm{WO} / 2017 / 211961$.

Lu, S.-Y., Hamerton I., 2002, "Recent developments in the chemistry of halogen-free flame retardant polymers." Progress in polymer science 27(8): 1661-1712.

Madakbaş, S., Çakmakçı E., Kahraman M. V., 2013, "Preparation and thermal properties of polyacrylonitrile/hexagonal boron nitride composites." Thermochimica Acta 552: 1-4.

Pekdemir, M. E., 2020, “Poli (Vinil klorür)/Fe3 $\mathrm{O}_{4}$ manyetik nanopartikül kompozitlerinin sentezi, termal ve elektriksel özelliklerinin incelenmesi." Afyon Kocatepe Üniversitesi Fen ve Mühendislik Bilimleri Dergisi, 20(5), 802-809.

Rudolph, S., 1993, "Composition and application of coatings based on boron nitride." Interceram 42(5): 302305.

Sahin, T., 2011, "Mechanical and Thermal Properties of Colemanite Filled Polypropylene." KGK. Kautschuk, Gummi, Kunststoffe 64(9): 16-21.

Sang, B., Li, Z. W., Li, X. H., Yu, L. G., Zhang, Z. J., 2017, “Titanate nanotubes decorated graphene oxide nanocomposites: preparation, flame retardancy, and photodegradation." Nanoscale research letters, 12(1), 1-12.

Seyhan, A. T., Göncü Y., Durukan O., Akay A., Ay N., 2017, "Silanization of boron nitride nanosheets (BNNSs) through microfluidization and their use for producing thermally conductive and electrically insulating polymer nanocomposites." Journal of Solid State Chemistry 249: 98-107.

Wang, R.-M., Zheng S.-R., Zheng Y. G., 2011, Polymer matrix composites and technology, Elsevier. 